\title{
Description of the Chondroepitroclearis Muscle and its Relationship to the Median Nerve in a Korean Corpse
}

\author{
Descripción del Músculo Condroepincondilar Medial y su \\ Relación con el Nervio Mediano en un Cadáver Coreano
}

Jongwan Kim'; Jae-Ho Lee ${ }^{1}$ \& Yongwook Jung²

\begin{abstract}
KIM, J.; LEE, J. H. \& JUNG, Y. Description of the chondroepitroclearis muscle and its relationship to the median nerve in a Korean corpse. Int. J. Morphol., 36(4):1180-1182, 2018.

SUMMARY: Anomalous muscle slips of pectoralis major have been reported on several cases in the literature. Among these, chondroepitroclearis muscle is an extremely rare aberrant muscular slip originating from the pectoral region. During an educational dissection, chondroepitroclearis muscle was found on the right side in a Korean cadaver. Tendinous muscular slip originated from pectoralis major muscle, crossing the neurovascular bundle in the arm, and inserted onto medial epicondyle of the humerus. Clinical significance of these anomalous slip can cause median nerve entrapment and functionally limited movement of the humerus. We report a case of tendinous chondroepitroclearis muscle and discuss its clinical and embryological significance.
\end{abstract}

KEY WORDS: Chondroepitroclearis muscle; Pectoralis major muscle; Median nerve; Variation.

\section{INTRODUCTION}

There are many anatomical variations in muscular structure of upper limb. Anatomical variations of pectoralis major muscle are noteworthy, not only because of their extreme rarity but also for their phylogenetic and clinical significance. The chondroepitroclearis muscle (CET) is an extremely rare muscular variation that may arise from pectoralis major muscle, costal cartilages, or the aponeurosis of the external oblique muscle (Loukas et al., 2005; Samuel \& Vollala, 2008). The insertion of these rare muscular slip is also varied (Chiba et al., 1983; Bergman, 1991; Flaherty et al., 1999). The CET reports a small number of cases as an anomalous muscle slip in the literature globally (Landry, 1958; Ohtani et al., 1986; Sarikcioglu et al., 2004; Loukas et al.). CET usually crosses the neurovascular structures of the arm. Therefore, their compression is a major complication (Voto \& Weiner, 1987; Samuel \& Vollala). Detailed information about such variant muscular slip is extremely essential to the clinicians for their treatment strategy, however, CET has not been reported in the Korean population.

In the present case, the authors demonstrated a rare case of CET and tried to learn its clinical significance. This report may help not only anatomist but also orthopedic surgeons, the neurologists and radiologists in their diagnostic and surgical approaches of median neuropathy.

\section{CASE REPORT}

During routine cadaveric dissection for the medical students, we observed a case of unilateral occurrence of tendinous CET in the right upper limb of cadaver of a 72year-old Korean female. The CET originated from the inferolateral margin of the pectoralis major near its insertion in right side and then descended downward and obliquely in relation to medial side of the arm. It coursed anterolateral to the short head of biceps brachii muscle and crossed the neurovascular bundles in the arm, especially the median nerve (Fig. 1). Finally, it inserted onto the medial epicondyle of the humerus near the common origin of flexors of forearm. It was measured approximately $18.6 \mathrm{~cm}$ in length and $0.9 \mathrm{~cm}$ in width at its broadest point. No arterial or nerve supply or evidence of their connections was found. In addition, there was no evidence of other accessory or anomalous muscles such as axillary arch muscles in the present cadaver.

\footnotetext{
${ }^{1}$ Department of Anatomy, School of Medicine, Keimyung University, Daegu, Republic of Korea.

${ }^{2}$ Department of Anatomy, College of Medicine, Dongguk University, Gyeongju Republic of Korea.
} 


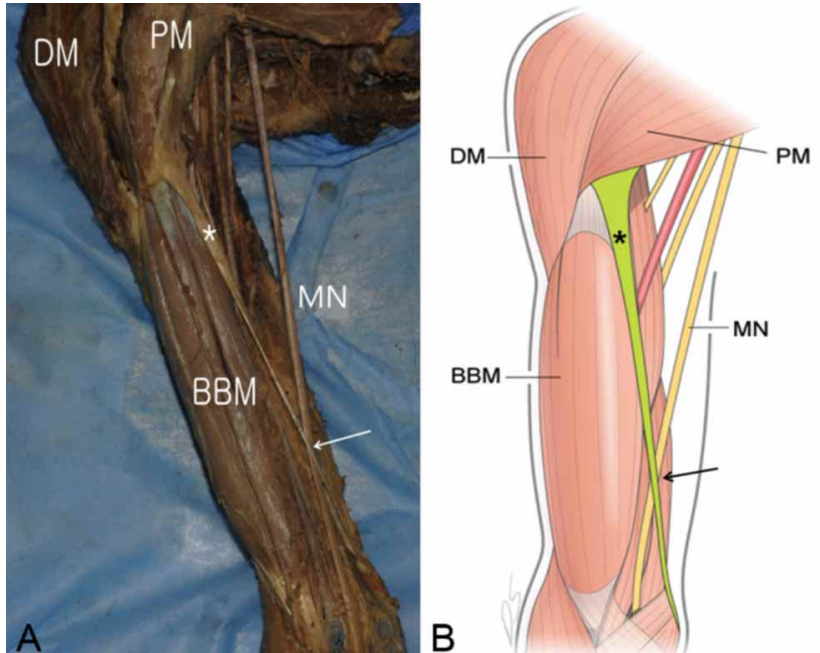

Fig. 1. Photograph (A) and schematic drawing (B) of the right upper limb. Tendinous-like chondroepitroclearis (asterics) originated from the inferolateral margin of the pectoralis major and inserted into the medial epicondyle of the humerus. It directly crossed the median nerve (arrows) during abduction. DM, deltoid muscle; PM, pectoralis major msucle; BBM, biceps brachii muscle; MN, median nerve.

\section{DISCUSSION}

Chondroepitrochlearis muscle (CET) is an anomalous muscular slip arising from the cartilages or costochondral junctions of the thorax, crossing the axilla and inserting into medial humeral epicondyle or medial intermuscular septum. The first case of CET was described by Calori in 1867 and since then, only 30 cases have been reported until now. Bergman et al. (2016) in their book on anatomical variations refer to 'costoepitrochlearis, chondroepitrochlearis, or chondrohumeralis' and describe the anomaly as a muscular slip that arises from one or more ribs, crosses the axilla, and inserts into the medial intermuscular or medial humeral epicondyle (Samuel \& Vollala). It originated from the ribs or the costal cartilages or the aponeurosis of the external oblique muscle (Samuel \& Vollala), and it inserted into the medial epicondyle of the humerus and to the brachial fascia, medial intermuscular septum or medial aspect of the humerus (Spinner et al., 1991). These results indicate that the origin and insertion of this muscle in the present report parallels that described by previous reports. In the present case, this variant muscular slip originated from the inferior margin of pectoralis major and inserted onto medial epicondyle of the humerus in paralleling with previous cases. However, this is a first case of tendinous CET in Korean population.

Previous studies suggested that CET tend to be associated with other muscular variations especially axillary arch muscles. And it has been found more frequently in infants with Patau syndrome (trisomy 13 with a Robertsonian translocation) (Aziz, 1980) and Edward syndrome (trisomy 18) at autopsy (Bersu \& Ramirez-Castro, 1977). However, our case did not accompany any other muscular variations or congenital anomaly. Its association should be confirmed by further larger study.

The presence of CET can create various clinical problems. Some complained the intermittent numbness on forearm and hand. And it may cause functional disability, such as ulnar nerve entrapment or restriction of abduction in glenohumeral joint. In addition to functional and neurological impairments, the presence of the CET can also present cosmetic deformities, giving the appearance of a pterygium within the axillary fold. In present case, it directly compressed the median nerve during abduction limiting normal range of motion of the upper limb. Thus, the knowledge of these muscle variations may be important for the clinicians for better diagnosis and treatment.

During embryogenesis, the genetic code for such atavistic muscle is normally suppressed as postulated by Barash et al. (1970). In about fifth week of intrauterine life, the pectoral musculature is derived from the ventral limb bud masses from the myoblasts. These myoblasts eventually migrate out of the last five cervical and the first thoracic myotomes into the developing limb buds. Through a combination of migration, fusion and apoptosis of the muscle cell precursors, the pectoral muscles assume their final forms. The persistence of a muscle slip in the form of the CET results due to the failure of apoptosis to occur at the right time in the myoblasts (Padavinangadi et al., 2016). It has also been considered that CET muscle slip is the result of absence of the twisted insertion of the pectoralis major (Palagama et al., 2016).

KIM, J.; LEE, J. H. \& JUNG, Y. Descripción del músculo condroepincondilar medial y su relación con el nervio mediano en un cadáver coreano. Int. J. Morphol., 36(4):1180-1182, 2018.

RESUMEN: En la literatura se han reportado fascículos anómalos del músculo pectoral mayor. Entre estos, el condroepicondilar medial es un fascículo muscular aberrante extremadamente raro que se origina en la región pectoral. Durante una disección educativa, se encontró esta variación en el lado derecho de un cadáver coreano. El fascículo muscular tendinoso se originó a partir del músculo pectoral mayor, cruzando el paquete neurovascular en el brazo, y se insertó en el epicóndilo medial del húmero. La importancia clínica de estos fascículos anómalos radica en la posibilidad de causar el atrapamiento del nervio mediano, causando un movimiento funcionalmente limitado del húmero. Divulgamos un caso de músculo condroepicondilar medial tendinoso y discutimos su significado clínico y embriológico.

PALABRAS CLAVE: Músculo condroepicondilar medial; Músculo pectoral mayor; Nervio mediano; Variación anatómica. 


\section{REFERENCES}

Aziz, M. A. Anatomical defects in a case of trisomy 13 with a D/D translocation. Teratology, 22(2):217-27, 1980.

Barash, B. A.; Freedman, L. \& Opitz, J. M. Anatomic studies in the 18trisomy syndrome. Birth Defects Orig. Artic. Ser., 6(4):3-15, 1970

Bergman, R. A. Doubled pectoralis quartus, axillary arch, chondroepitrochlearis, and the twist of the tendon of pectoralis major. Anat. Anz., 173(1):23-6, 1991.

Bergman, R. A.; Tubbs, R. S.; Shoja, M. M. \& Loukas, M. Bergman's comprehensive encyclopedia of human anatomic variation. Hoboken, John Wiley \& Sons, 2016.

Bersu, E. T. \& Ramirez-Castro, J. L. Anatomical analysis of the developmental effects of aneuploidy in man--the 18-trisomy syndrome: I. Anomalies of the head and neck. Am. J. Med. Genet., 1(2):173-93, 1977.

Chiba, S.; Suzuki, T. \& Kasai, T. A rare anomaly of the pectoralis major-the chondroepitrochlearis. Okajimas Folia Anat. Jpn., 60(2-3):175-85, 1983.

Flaherty, G.; O'Neill, M. N. \& Folan-Curran, J. Case report: bilateral occurrence of a chondroepitrochlearis muscle. J. Anat., 194(Pt. 2):313$5,1999$.

Landry, S. O. Jr. The phylogenetic significance of the chondro-epitrochlearis muscle and its accompanying pectoral abnormalities. J. Anat., 92(1):5761, 1958.

Loukas, M.; Louis, R. G. Jr. \& Kwiatkowska, M. Chondroepitrochlearis muscle, a case report and a suggested revision of the current nomenclature. Surg. Radiol. Anat., 27(4):354-6, 2005.

Ohtani, O.; Kikuta, A.; Taguchi, T.; Ohtsuka, A. \& Murakami, T. The chondro-epitrochlearis, an aberrant slip of the pectoralis major. Okajimas Folia Anat. Jpn., 63(2-3):127-32, 1986.

Padavinangadi, A.; Kumar, N.; Rao, M. K. \& Nayak, S. B. Unilateral existence of chondro-epitrochlearis: its embryological perspectives and clinical implications. J. Clin. Diagn. Res., 10(7):AD01-2, 2016.

Palagama, S. P. W.; Tedman, R. A.; Barton, M. J. \& Forwood, M. R. Bilateral chondroepitrochlearis muscle: case report, phylogenetic analysis, and clinical significance. Anat. Res. Int., 2016:5402081, 2016.

Samuel, V. P. \& Vollala, V. R. Unusual pectoralis major muscle: the chondroepitrochlearis. Anat. Sci. Int., 83(4):277-9, 2008.

Sarikcioglu, L.; Yildirim, F. B. \& Chiba, S. Unilateral occurrence of a chondroepitrochlearis muscle. Clin. Anat., 17(3):272-5, 2004.

Spinner, R. J.; Carmichael, S. W. \& Spinner, M. Infraclavicular ulnar nerve entrapment due to a chondroepitrochlearis muscle. J. Hand Surg. Br., 16(3):315-7, 1991.

Voto, S. J. \& Weiner, D. S. The chondroepitrochlearis muscle. J. Pediatr. Orthop., 7(2):213-4, 1987.

\section{Corresponding author: Yongwook Jung \\ Department of Anatomy Dongguk University School of Medicine \\ 87 Dongdae-ro Gyeongju 780-350 REPUBLIC OF KOREA}

Email: anato82@dsmc.or.kr

Received: 27-04-2018

Accepted: 06-08-2018 